\title{
The modifiers of amyotrophic lateral sclerosis survival and clinical trial design
}

\author{
Bin Zhou* \\ Translational Research Informatics Center, Foundation for Biomedical Research and Innovation, Kobe, Japan
}

\begin{abstract}
Amyotrophic lateral sclerosis (ALS) patients with different median survival also show a different progression speed. Genetic studies identified several genes associated with an increased risk and/or shorter survival of ALS. In the present review, we discuss some issues critical for the definition of survival and identification of prognostic factors of ALS. More studies are needed to exclude confounds and find the true intrinsic risk factors affecting the disease onset and/or the prognosis of this disease. We propose that some mutated genes may act more as survival modifiers than as risk factors. Recruiting a homogeneous group of patients based on their genetic background is another approach that should be considered when drafting the inclusion criteria during the trial design. This approach may facilitate the development of therapies for ALS.
\end{abstract}

\begin{abstract}
Abbreviations: ALS: Amyotrophic lateral sclerosis; NIPPV: Noninvasive Positve Pressure Ventilation; C90rf72: Chromosome 9 open reading frame72; TARDBP: TAR DNA-binding protein 43 gene; FUS: Fused in Sarcoma gene; SOD1: Superoxide dismutase 1; KIFAP3: Kinesin-associated protein 3; CX3CR1: C-X3-C Motif Chemokine Receptor 1; UNC13A: Unc-13 homolog A; CAMTA1: calmodulin binding transcription activator 1; SMN1: Survival Motor Neuron 1; ATAXN2: gene encoding protein Ataxin-2; ALSFRS-R: ALS Functional Rating Scale-Revised; PEG: percutaneous endoscopic gastrostomy; SNV: single nucleotide variation
\end{abstract}

\section{Review}

Amyotrophic lateral sclerosis (ALS) is a neurodegenerative disease that affects upper and lower motoneurons resulting in progressive weakness of voluntary muscles and death from respiratory failure. Arthur [1] estimated that the number of people with ALS will increase from 222,801 in 2015 to 376,674 in 2040 . The prognosis is highly heterogeneous entailing large differences in the speed of progression of the disease. It is unknown why some patients with ALS deteriorate much faster, or survive for a shorter period, than others. Because of the different survival and progression speeds, the factors associated with the speed of progression have to be taken into account during the design of the clinical trial design. There is also a geographic difference in survival. Therefore, clarifying the survival and true surrogate factors for stratification will facilitate clinical trial design and the global development of therapies for patients affected by ALS.

Our literature analysis revealed that the median survival varies according to the individual and the region of origin. The median survival in Europe and North America is approximately 3 years, with individual studies ranging from 20 to 50 months, and $10-20 \%$ of patients with ALS survive more than 10 years [2]. The median survival in Asia, excluding Japan and Brazil, ranges from 66 to 116 months, which is approximately twice the median survival measured in most of Europe and North America [3-29]. Japan's median survival (22.8 to 37 months) in is similar to the survival observed in Europe [3-29]. The variability of ALS onset indicates that a time-dependent exposure to a combination of genetic and environmental risk factors may be involved in the pathogenesis of ALS. Whether this region-specific survival is also influenced by these factors needs further research and analysis (Table 1).

When comparing the median survival of patients with ALS obtained from different studies, one important issue to consider is the definition of survival. Two possible starting points can be defined: either the onset of the disease or the diagnosis. Similarly, two endpoints (the death or the use of non-invasive ventilation, or tracheostomy) can be defined. Indeed, the use of non-invasive ventilation or tracheostomy can greatly prolong survival. Sanchoj [30] reported that non-invasive ventilation prolonged the survival by a median of 15 months. The median survival after tracheostomy has been reported to be 30 months [31], which is almost equal to the reported overall median survival of patients with ALS. In Japan, invasive ventilation and tracheostomy extended median survival by 74 months, while non-invasive ventilation extended survival by 48 months, when compared with a non-ventilation-supported group [32]. The major reasons on whether to use non-invasive ventilation or tracheostomy can depend on the willingness of patients or their relatives and their economic status and not necessarily the severity of disease. Indeed, developing an international registry of ALS with a standard protocol for coding the geographic data relative to the median survival is an emerging objective yet to be accomplished.

In terms of the prognostic factors associated with survival in patients with ALS, old age and bulbar onset have been consistently reported as an indication of a worse clinical outcome than younger age and limb onset. The influence of sex and delayed on the prognosis

*Correspondence to: Bin Zhou, MD, PhD, 1-5-4 Minatojima-minamimachi, Chuo-ku, Translational Research Informatics Center, Foundation for Biomedical Research and Innovation, Kobe, 650-0047, Japan, Tel: +81-78-3039093; Fax: +81-78-3039094; E-mail: zhoubin@tri-kobe.org

Key words: amyotrophic lateral sclerosis, survival, modifier, genetic factor, clinical trial design

Received: September 20, 2016; Accepted: November 04, 2016; Published: November 07, 2016 
Table 1. Median survival of ALS in countries.

\begin{tabular}{|l|l|l|}
\hline Continent & Author & Median survival(range) \\
\hline Europe & Chioadriano [3], 2013 & $40.8 \mathrm{~m}$ (26.4-72.6), Italy \\
\hline & marinbenoit [4], 2016 & $25 \mathrm{~m}(23-34)$, north europe \\
\hline & marinbenoit [4], 2016 & $30 \mathrm{~m}$ (25-34), western europe \\
\hline & Zoccolella s [5], 2008 & $28 \mathrm{~m}$, Italy \\
\hline & Millul a [6], 2005 & $39.2 \mathrm{~m}$, Italy \\
\hline & Tysnesob [7],1991 & $28 \mathrm{~m}$, Norway \\
\hline & magnus t [8], 2002 & $37-58$, German \\
\hline & thijs v [9], 2000 & $32 \mathrm{~m}$, Belgium \\
\hline & Sanjuan-lopez p [10], 2014 & $28 \mathrm{~m}$, Spain \\
\hline & Bandettini di poggio[11], 2013 & $45 \mathrm{~m}$, Italy \\
\hline & Gordon ph [12], 2012 & $40.0 \mathrm{~m}$, france \\
\hline & Borghero [13],2014 & $50.4 \mathrm{~m}$, Italy $(27.6-120 \mathrm{~m})$ \\
\hline & yoshida s [14], 1986 & $23.8 \mathrm{~m}$, Japan \\
\hline & kahana e [15],1984 & $36 \mathrm{~m}$, Israel \\
\hline & Sajjadi M [16],2010 & $48 \mathrm{~m}$, Iran \\
\hline & lee ctc [17], 2013 & $66.6 \mathrm{~m}$, Taiwan \\
\hline & Nalini a[18],2008 & $114.8 \mathrm{~m}$, India \\
\hline & kanai k [19], 2012 & $37 \mathrm{~m}$, Japan \\
\hline & fujimura-kiyono c [20], & $18-26 \mathrm{~m}$, Japan \\
\hline & Chen lu [21],2015 & $74 \mathrm{~m}$, China \\
\hline & mcguire v [22], 1996 & $32 \mathrm{~m}$, north america \\
\hline & norris f [23], 1993 & $39.5 \mathrm{~m}$, north america \\
\hline & marinbenoit[4],2016 & $26.2 \mathrm{~m}$, america \\
\hline & del Aguila MA [24],2003 & $32 \mathrm{~m}$, north america \\
\hline & cetin h [25], 2015 & $22.5 \mathrm{~m}$, america \\
\hline & paulukonis ST[26],2015 & $31.2 \mathrm{~m}$, America \\
\hline & loureiromp [27], & $49 \mathrm{~m}$, brazil \\
\hline & Moura MC [28] & $45.7 \mathrm{~m}$ men and 39.3m women \\
\hline & & \\
\hline & & \\
\hline & &
\end{tabular}

diagnosis are still controversial $[2,33,34,22]$. Respiratory onset is also a negative prognostic factor $[35,36]$ although non-invasive ventilation can significantly improve survival [37]. Interestingly, the lower frequency of bulbar-onset and younger onset in Chinese patients with an extended survival supports these findings [22]. In terms of therapeutic factors, riluzole may improve median survival by several months and NIPPV has been shown to add 205 days to median survival and it also improves the quality of life $[38,39]$. In addition to the characteristics associated with the rapid progression of disease, some genes may affect the survival in ALS.

About $85-90 \%$ of ALS cases are sporadic, while $10-15 \%$ has a family history. Sporadic ALS is considered to be a complex disease with multiple genetic risk factors contributing to its pathogenesis. Mutations of 126 genes have been shown to be associated with ALS. Identification of genes that co-occur frequently may provide relevant insight into the underlying mechanism of motor neuron degeneration. The most commonly identified genes to be associated with a high risk of ALS are C9orf72 ('chromosome 9 open reading frame72'), TARDBP (TAR DNA-binding protein 43 gene), FUS (Fused in Sarcoma gene), and SOD1 (superoxide dismutase 1). Other genes that have been found to be rarely associated with ALS include KIFAP3 (Kinesin-associated protein 3), CX3CR1 (C-X3-C Motif Chemokine Receptor 1), UNC13A (Unc-13 homolog A), CAMTA1 (calmodulin binding transcription activator 1), SMN1 (Survival Motor Neuron 1), and ATAXN2 (gene encoding protein Ataxin-2). Although these genes showed higher frequency in patients with ALS than in healthy controls, however these mutant genes are present in less than $50 \%$ of all ALS patients. As shown in Table 2 [39-56], the mutation of SOD1 accounts for the occurrence of $4-20 \%$ of familial ALS and $1-5 \%$ of sporadic cases, C9orf 72 accounts
Table 2. Frequency of mutant risk genes in ALS patients.

\begin{tabular}{|c|c|c|c|}
\hline \multirow[t]{2}{*}{ Gene } & \multirow[t]{2}{*}{ Author, Country } & \multicolumn{2}{|c|}{ Frequency in ALS (\%) } \\
\hline & & fALS & sALS \\
\hline \multirow[t]{9}{*}{ C9orf72 } & Ratti a[39],2012 & 23.9 & 5.1 \\
\hline & OGAKI[40],2015,JAPAN & 0 & 0.4 \\
\hline & Houlh[41], 2016,China & 8.3 & NA \\
\hline & He j[42], 2015, China & NA & 0.3 \\
\hline & Ozoguz a[43],2015, Turkey & 18.3 & 3.1 \\
\hline & Bertolin c[44], 2014, Italy & 22 & 5 \\
\hline & Borghero[13], 2014,Italy & 33 & 6.5 \\
\hline & Abramycheva [45] 2015,Russia & 15 & 2.5 \\
\hline & Milecamps [46], 2010,France & 46 & 8 \\
\hline \multirow[t]{6}{*}{ SOD1 } & Houlh [41], 2016,China & 20 & 1.9 \\
\hline & Ozoguz a [43],2015, Turkey & 12.2 & 0 \\
\hline & Canosa a[47 ],2014, Italy & 13.6 & 0.7 \\
\hline & Kwon MJ[48], 2012,Korea & 77.8 & 1.2 \\
\hline & Milecamps[46], 2010,France & 12.4 & NA \\
\hline & Borghero [13], 2014,Italy & 4 & 0 \\
\hline \multirow[t]{7}{*}{ TARDBP } & Corrado 1 [49 ], Italy,2009 & 2.7 & NA \\
\hline & Iida A, 2010[50], Japan & NA & 0.29 \\
\hline & Kamada[51],2009, & 0.33 & 0 \\
\hline & zouzy[52],2012,China & NA & 0.73 \\
\hline & Ozoguz a[44],2015, Turkey & 3.7 & NA \\
\hline & Milecamps[46], 2010,France & 4 & NA \\
\hline & Borghero[13], 2014,Italy & 25 & 19.3 \\
\hline \multirow[t]{8}{*}{ FUS } & Houlh[41], 2016,China & 13.3 & 0 \\
\hline & Syriani[53], 2011, Spain & 8 & NA \\
\hline & Waibel[54],2010, German & 2.4 & NA \\
\hline & Drepper [55], 2009, German & 6.9 & NA \\
\hline & Corrado [49], 2009, Italy & 4.4 & NA \\
\hline & Van damme [56], 2010,Belgium & 2.9 & NA \\
\hline & Milecamps[46], 2010,France & 4 & NA \\
\hline & Ozoguz [44],2015, Turkey & 5 & NA \\
\hline
\end{tabular}

for $8.3-33 \%$ of familial ALS and $0.3-6.5 \%$ of sporadic cases, mutations in TARDBP account for $5-10 \%$ while mutations in FUS for $5 \%$ of familial ALS. The most frequent four genes in familiar ALS account for about $2-6 \%$ in sporadic ALS which represents $85-90 \%$ of all ALS cases. The remaining mutant genes are very rare in ALS. The contribution of the individual's genetic background to the pathogenesis of ALS has not been well characterized and further the contribution is limited because of the low frequency of mutation in sporadic cases. Most patients do not carry any of the mutations of the genes aforementioned. The relatively low frequency of these genes in sporadic ALS suggests that the pathogenesis is triggered by an interaction between genes and environmental factors. However, this hypothesis requires further experimental support. However, we know that patients with ALS are heterogeneous, i.e., they display an elevated variability in the speed of the disease progression and the prognosis. We therefore speculate that differences in genetic factors provide the molecular basis for the variability observed in both the in survival and onset.

Some genes are not only risk factors, but they may also be survival modifiers. Several studies have shown that UNC13A [3,57,58,] and ATXN2 $[59,60,61]$ are associated with shorter survival in ALS. The type of mutation lying in the TARDBP super rich glycine-residue domain was associated with the worst survival [62 ]. Some mutant genes showed association both in the increase of risk and shorter survival of ALS. A Meta-analysis indicated that ATXN2 gene mutation is found in $1-3.4 \%$ of patients affected by ALS, and results in an increased risk of ALS when compared with controls [63]. UNC13A is associated with 
both increased susceptibility and a shorter survival in ALS patients [58]. However this association was not replicated in all studies. In a sample of patients from the Netherlands that SNVs rs10419420:G >A of gene UNC13A was found exclusively in long survivors (3/25) and rs4808092:G $>$ A exclusively in short survivors [64]. Patients with ALS with expanded repeat sizes of ATXN2 gene ranged from rapidly progressive typical ALS to slowly progressive ALS with reduced sensory nerve action potentials [65]. Some research showed completed interaction. Patients carrying C9orf 72 had a median survival of 2.37 years, patients with a co-occurrence of C9orf72 and TARDBP p.A382T had a median survival of 3.1 years, and patients carrying TARDBP p.A382T had a survival of 6.5 years [13]. In a basic research, functional evidence of UNC-13/UNC13A regulating motor neuron degeneration [66] provided implied the modifier of some genes in ALS survival.

We know that old age and bulbar onset are associated with a severe prognosis. Some genetic mutations are believed to reduce survival and they are also associated with both the age at onset and bulbar onset. The interactions between genetic factors entail different combinations of genes such that they may exert different influences on the risk and survival in patients with ALS [13]. The hypothesis is that some mutant genes may act more as survival modifiers than risk factors. To exclude confounds and find true intrinsic risk factors for disease onset and/or prognosis is important for clarifying Ethnic and individual heterogeneity.

The traditional stratification procedure adopted in clinical trials for ALS to divide patients by age at onset and bulbar onset is no longer sufficient and adequate. Indeed, the respiratory status at the beginning of the study and the disease progression as measured by the ALSFRS- $R$ should be part of the criteria used for stratification. Selecting a homogeneous group based on the genetic background of the patients is another approach that has to be taken into consideration when drafting the inclusion criteria in trial design. However, the effect of PEG and NIPPV on ALS outcome in the treatment section of the protocol should also be noted when we evaluate the effect of one therapy in a clinical trial.

A further issue that needs to be addressed is which factor, or interaction of factors, results in the rapid progression of ALS. Identifying the genetic factors influencing susceptibility, age at onset, and survival of ALS may provide insight into the pathogenic mechanism underlying ALS, motivate the search for new pharmacologic targets, and facilitate clinical trial design for this fatal neurodegenerative disease. Future research should aim to develop an international registry using a standard protocol and central data center to guarantee the quality of studies. The use of the multivariate Cox regression is also important. Among the several prognostic factors identified so far, including factors such as the age at onset, bulbar onset, and genes that increase risk (e.g., C9orf72, TARDBP, FUS, SOD1) or modify survival (e.g., ATXN2, UNC13A, KIFAP3, CX3CR1), more efforts should be done to determine the factor, or interaction of factors, that affects ALS prognosis. Gaining insight into the complex factors that affect ALS prognosis will both promote the identification of novel therapeutic targets for slowing the progression of the disease and support the development of appropriate clinical trials.

\section{References}

1. Arthur KC, Calvo A, Price T, Geiger JT, Chiò A, et al. (2016) Projected increase in amyotrophic lateral sclerosis from 2015 to 2040. Nat Commun 7: 12408. [Crossref]

2. Chiò A, Logroscino G, Hardiman O, Swingler R, Mitchell D, et al. (2009) Prognostic factors in ALS: A critical review. Amyotroph Lateral Scler 10: 310-323. [Crossref]
3. Chiò A, Mora G, Restagno G, Brunetti M, Ossola I, et al. (2013) UNC13A influences survival in Italian amyotrophic lateral sclerosis patients: a population-based study. Neurobiol Aging 34: 357. [Crossref]

4. Marin B, Logroscino G, Boumédiene F, Labrunie A, Couratier P, et al. (2016) Clinical and demographic factors and outcome of amyotrophic lateral sclerosis in relation to population ancestral origin. Eur J Epidemiol 31: 229-245. [Crossref]

5. Zoccolella S, Beghi E, Palagano G, Fraddosio A, Guerra V, et al.(2008) Analysis of survival and prognostic factors in amyotrophic lateral sclerosis: a population based study. J Neurol Neurosurg Psychiatry 79: 33-37. [Crossref]

6. Millul A, Beghi E, Logroscino G, Micheli A, Vitelli E, et al. (2005) Survival of patients with amyotrophic lateral sclerosis in a population-based registry. Neuroepidemiology 25: 114-119. [Crossref]

7. Tysnes OB, Vollset SE, Larsen JP, Aarli JA (1994) Prognostic factors and survival in amyotrophic lateral sclerosis. Neuroepidemiology 13: 226-235. [Crossref]

8. Magnus T, Beck M, Giess R, Puls I, Naumann M, et al. (2002) Disease progression in amyotrophic lateral sclerosis: predictors of survival. Muscle Nerve 25: 709-714. [Crossref]

9. Thijs V, Peeters E, Theys P, Matthijs G, Robberecht W (2000). Demographic characteristics and prognosis in a Flemish amyotrophic lateral sclerosis population. Acta Neurol Belg 100: 84-90. [Crossref]

10. Sanjuán-López P, Valiño-López P, Ricoy-Gabaldón J, Verea-Hernando H (2014) Amyotrophic lateral sclerosis: impact of pulmonary follow-up and mechanical ventilation on survival. A study of 114 cases. Arch Bronconeumol 50: 509-513. [Crossref]

11. Bandettini di Poggio M, Sormani MP, Truffelli R, Mandich P, Origone P, et al (2013) Clinical epidemiology of ALS in Liguria, Italy. Amyotroph Lateral Scler Frontotemporal Degener 14: 52-57. [Crossref]

12. Gordon PH, Salachas F, Bruneteau G, Pradat PF, Lacomblez L, et al. (2012) Improving survival in a large French ALS center cohort. J Neurol 259: 1788-1792. [Crossref]

13. Borghero G, Pugliatti M, Marrosu F, Marrosu MG, Murru MR, et al. (2014) Genetic architecture of ALS in Sardinia. Neurobiol Aging 35: 2882. [Crossref]

14. Yoshida S, Mulder DW, Kurland LT, Chu CP, Okazaki H (1986) Follow-up study on amyotrophic lateral sclerosis in Rochester, Minn., 1925 through 1984 Neuroepidemiology 5: 61-70. [Crossref]

15. Kahana E, Zilber N (1984) Changes in the incidence of amyotrophic lateral sclerosis in Israel. Arch Neurol 41: 157-160. [Crossref]

16. Sajjadi M, Etemadifar M, Nemati A, Ghazavi H, Basiri K, et al. (2010) Epidemiology of amyotrophic lateral sclerosis in Isfahan, Iran. Eur J Neurol 17: 984-989. [Crossref]

17. Lee CT, Chiu YW, Wang KC, Hwang CS, Lin KH, et al. (2013) Riluzole and prognostic factors in amyotrophic lateral sclerosis long-term and short-term survival: a populationbased study of 1149 cases in Taiwan. J Epidemiol 23: 35-40. [Crossref]

18. Nalini A, Thennarasu K, Gourie-Devi M, Shenoy S, Kulshreshtha D (2008) Clinica characteristics and survival pattern of 1,153 patients with amyotrophic lateral sclerosis: experience over 30 years from India. J Neurol Sci 272: 60-70. [Crossref]

19. Kanai K, Shibuya K, Sato Y, Misawa S, Nasu S, et al. (2012) Motor axonal excitability properties are strong predictors for survival in amyotrophic lateral sclerosis. $J$ Neurol Neurosurg Psychiatry 83: 734-738. [Crossref]

20. Fujimura-Kiyono C, Kimura F, Ishida S, Nakajima H, Hosokawa T, et al. (2011) Onset and spreading patterns of lower motor neuron involvements predict survival in sporadic amyotrophic lateral sclerosis. J Neurol Neurosurg Psychiatry 82: 1244-1249. [Crossref]

21. Chen L, Zhang B, Chen R, Tang L, Liu R, et al (2015) Natural history and clinica features of sporadic amyotrophic lateral sclerosis in China. $J$ Neurol Neurosurg Psychiatry 86: 1075-1081. [Crossref]

22. McGuire V, Longstreth WT Jr, Koepsell TD, van Belle G (1996) Incidence of amyotrophic lateral sclerosis in three counties in western Washington state. Neurology 47: 571-573. [Crossref]

23. Norris F, Shepherd R, Denys E, U K, Mukai E, et al. (1993) Onset, natural history and outcome in idiopathic adult motor neuron disease. J Neurol Sci 118: 48-55. [Crossref]

24. del Aguila MA, Longstreth WT Jr, McGuire V, Koepsell TD, van Belle G (2003) Prognosis in amyotrophic lateral sclerosis: a population-based study. Neurology 60: 813-819. [Crossref]

25. Cetin H, Rath J, Füzi J, Reichardt B, Fülöp G, et al. (2015) Epidemiology of amyotrophic 
lateral sclerosis and effect of riluzole on disease course. Neuroepidemiology 44: 6-15. [Crossref]

26. Paulukonis ST, Roberts EM, Valle JP, Collins NN, English PB, et al. (2015) Survival and Cause of Death among a Cohort of Confirmed Amyotrophic Lateral Sclerosis Cases. PLoS One 10: e0131965. [Crossref]

27. Loureiro MP, Gress CH, Thuler LC, Alvarenga RM, Lima JM (2012) Clinical aspects of amyotrophic lateral sclerosis in Rio de Janeiro/Brazil. J Neurol Sci 316: 61-66. [Crossref]

28. Moura MC, Casulari LA, Carvalho Garbi Novaes MR (2016) Ethnic and demographic incidence of amyotrophic lateral sclerosis (ALS) in Brazil: A population based study. Amyotroph Lateral Scler Frontotemporal Degener 17: 275-281. [Crossref]

29. Sancho J, Servera E, Morelot-Panzini C, Salachas F, Similowski T, et al. (2014) Noninvasive ventilation effectiveness and the effect of ventilatory mode on survival in ALS patients. Amyotroph Lateral Scler Frontotemporal Degener 15: 55-61. [Crossref]

30. Veronese S, Valle A, Chiò A, Calvo A, Oliver D (2014) The last months of life of people with amyotrophic lateral sclerosis in mechanical invasive ventilation: a qualitative study. Amyotroph Lateral Scler Frontotemporal Degener 15: 499-504. [Crossref]

31. Tagami M, Kimura F, Nakajima H, Ishida S, Fujiwara S, et al. (2014) Tracheostomy and invasive ventilation in Japanese ALS patients: decision-making and survival analysis: 1990-2010. J Neurol Sci 344: 158-164. [Crossref]

32. Louwerse ES, Visser CE, Bossuyt PM, Weverling GJ (1997) Amyotrophic lateral sclerosis: mortality risk during the course of the disease and prognostic factors. The Netherlands ALS Consortium. J Neurol Sci 152 Suppl 1: S10-17. [Crossref]

33. Testa D, Lovati R, Ferrarini M, Salmoiraghi F, Filippini G (2004) Survival of 793 patients with amyotrophic lateral sclerosis diagnosed over a 28-year period. Amyotroph Lateral Scler Other Motor Neuron Disord 5: 208-212. [Crossref]

34. Bourke SC, Shaw PJ, Gibson GJ (2001) Respiratory function vs sleep-disordered breathing as predictors of QOL in ALS. Neurology 57: 2040-2044. [Crossref]

35. de Carvalho M, Matias T, Coelho F, Evangelista T, Pinto A, et al. (1996) Motor neuron disease presenting with respiratory failure. J Neurol Sci 139 Suppl: 117-122. [Crossref]

36. Shoesmith CL, Findlater K, Rowe A, Strong MJ (2007) Prognosis of amyotrophic lateral sclerosis with respiratory onset. J Neurol Neurosurg Psychiatry 78: 629-631. [Crossref]

37. Pinto AC, Evangelista T, Carvalho M, Alves MA, et al. (1995) Respiratory assistance with a non-invasive ventilator (Bipap) in MND/ALS patients: survival rates in a controlled trial. J Neurol Sci 129 Suppl:19-26. [Crossref]

38. Ratti A, Corrado L, Castellotti B, Del Bo R, Fogh I, et al. (2012) C9ORF72 repeat expansion in a large Italian ALS cohort: evidence of a founder effect. Neurobiol Aging 33: 2528. [Crossref]

39. Ogaki K, Li Y, Atsuta N, Tomiyama H, Funayama M, et al. (2012) Analysis of C9orf72 repeat expansion in 563 Japanese patients with amyotrophic lateral sclerosis. Neurobiol Aging 33: 2527.e11-16. [Crossref]

40. Hou L, Jiao B, Xiao T, Zhou L, Zhou Z, et al. (2016) Screening of SOD1, FUS and TARDBP genes in patients with amyotrophic lateral sclerosis in central-southern China. Sci Rep 6: 32478. [Crossref]

41. He J, Tang L, Benyamin B, Shah S, Hemani G, et al. (2015) C9orf72 hexanucleotide repeat expansions in Chinese sporadic amyotrophic lateral sclerosis. Neurobiol Aging 36: 2660.e1-8. [Crossref]

42. Özoğuz A, Uyan Ö, Birdal G, Iskender C, Kartal E, et al. (2015) The distinct genetic pattern of ALS in Turkey and novel mutations. Neurobiol Aging 36: 1764. [Crossref]

43. Bertolin C, D'Ascenzo C, Querin G, Gaiani A, Boaretto F, et al. (2014) Improving the knowledge of amyotrophic lateral sclerosis genetics: novel SOD1 and FUS variants. Neurobiol Aging 35: 1212.e7-1212.e10. [Crossref]

44. Abramycheva NY, Lysogorskaia EV, Stepanova MS, Zakharova MN, Kovrazhkina EA, et al. (2015) C9ORF72 hexanucleotide repeat expansion in ALS patients from the Central European Russia population. Neurobiol Aging 36: 2908.e5-2908.e9. [Crossref]

45. Millecamps S, Salachas F, Cazeneuve C, Gordon P, Bricka B, et al. (2010) SOD1, ANG, VAPB, TARDBP, and FUS mutations in familial amyotrophic lateral sclerosis: genotype-phenotype correlations. J Med Genet 47: 554-560. [Crossref]

46. Canosa A, Calvo A, Moglia C, Barberis M, Brunetti M, et al. (2015) A novel p.E121G heterozygous missense mutation of SOD1 in an apparently sporadic ALS case with a 14-year course. Amyotroph Lateral Scler Frontotemporal Degener 16: 127-128.

47. Kwon MJ, Baek W, Ki CS, Kim HY, Koh SH, et al. (2012) Screening of the SOD1,
FUS, TARDBP, ANG, and OPTN mutations in Korean patients with familial and sporadic ALS. Neurobiol Aging 33: 1017.e17-23. [Crossref]

48. Millecamps S, Boillée S, Le Ber I, Seilhean D, Teyssou E, et al. (2012) Phenotype difference between ALS patients with expanded repeats in C9ORF72 and patients with mutations in other ALS-related genes. J Med Genet 49: 258-263. [Crossref]

49. Corrado L, Ratti A, Gellera C, Buratti E, Castellotti B, et al. (2009) High frequency of TARDBP gene mutations in Italian patients with amyotrophic lateral sclerosis. Hum Mutat 30: 688-694. [Crossref]

50. Iida A, Kamei T, Sano M, Oshima S, Tokuda T, et al. (2012) Large-scale screening of TARDBP mutation in amyotrophic lateral sclerosis in Japanese. Neurobiol Aging 33: 786-790. [Crossref]

51. Kamada M, Maruyama H, Tanaka E, Morino H, Wate R, et al. (2009) Screening for TARDBP mutations in Japanese familial amyotrophic lateral sclerosis. J Neurol Sci 284: 69-71. [Crossref]

52. Zou ZY, Peng Y, Wang XN, Liu MS, Li XG, et al. (2012) Screening of the TARDBP gene in familial and sporadic amyotrophic lateral sclerosis patients of Chinese origin. Neurobiol Aging 33: 2229.e11-2229.e18. [Crossref]

53. Syriani E, Morales M, Gamez J (2011) FUS/TLS gene mutations are the second most frequent cause of familial ALS in the Spanish population. Amyotroph Lateral Scler 12 118-123. [Crossref]

54. Waibel S, Neumann M, Rosenbohm A, Birve A, Volk AE, et al. (2013) Truncating mutations in FUS/TLS give rise to a more aggressive ALS-phenotype than missense mutations: a clinico-genetic study in Germany. Eur J Neurol 20: 540-546. [Crossref]

55. Drepper C, Herrmann T, Wessig C, Beck M, Sendtner M (2011) C-terminal FUS/ TLS mutations in familial and sporadic ALS in Germany. Neurobiol Aging 32: 548. [Crossref]

56. Damme PV, Goris A, Race V, Hersmus N, Dubois B, et al. (2010) The occurrence of mutations in FUS in a Belgian cohort of patients with familial ALS. Eur J Neurol 17: 754-756. [Crossref]

57. Gaastra B, Shatunov A, Pulit S, Jones AR, Sproviero W, et al. (2016) Rare genetic variation in UNC13A may modify survival in amyotrophic lateral sclerosis. Amyotroph Lateral Scler Frontotemporal Degener 1: 1-7. [Crossref]

58. Vidal-Taboada JM, Lopez-Lopez A, Salvado M, Lorenzo L, Garcia C, et al. (2015) UNC13A confers risk for sporadic ALS and influences survival in a Spanish cohort. $J$ Neurol 262: 2285-2292. [Crossref]

59. Diekstra FP, van Vught PW, van Rheenen W, Koppers M, Pasterkamp RJ, et al. (2012) UNC13A is a modifier of survival in amyotrophic lateral sclerosis. Neurobiol Aging 33: 630. [Crossref]

60. Lysogorskaia EV, Abramycheva NY, Zakharova MN, Stepanova MS, Moroz AA et al. (2015) Genetic studies of Russian patients with amyotrophic lateral sclerosis. Amyotroph Lateral Scler Frontotemporal Degener 17: 135-141.

61. Borghero G, Pugliatti M, Marrosu F, Marrosu MG, Murru MR, et al. (2015) ATXN2 is a modifier of phenotype in ALS patients of Sardinian ancestry. Neurobiol Aging 36: 2906. [Crossref]

62. Chiò A, Calvo A, Moglia C, Canosa A, Brunetti M, et al. (2015) ATXN2 polyQ intermediate repeats are a modifier of ALS survival. Neurology 84: 251-258. [Crossref]

63. Corcia P, Valdmanis P, Millecamps S, Lionnet C, Blasco H, et al. (2012) Phenotype and genotype analysis in amyotrophic lateral sclerosis with TARDBP gene mutations. Neurology 78: 1519-1526. [Crossref]

64. Wang MD, Little J, Gomes J, Cashman NR, Krewski D (2016). Identification of risk factors associated with onset and progression of amyotrophic lateral sclerosis using systematic review and meta-analysis. Neurotoxicology S0161-813X(16)30116-4. [Crossref]

65. Van Damme P, Veldink JH, van Blitterswijk M, Corveleyn A, van Vught PW, et al (2011) Expanded ATXN2 CAG repeat size in ALS identifies genetic overlap between ALS and SCA2. Neurology 76: 2066-2072. [Crossref]

66. Vérièpe J, Fossouo L, Parker JA (2015) Neurodegeneration in C. elegans models of ALS requires TIR-1/Sarm1 immune pathway activation in neurons. Nat Commun 6 : 7319.

Copyright: (C2016 Zhou B. This is an open-access article distributed under the terms of the Creative Commons Attribution License, which permits unrestricted use, distribution, and reproduction in any medium, provided the original author and source are credited. 